\title{
Characterizing practices and the sanitary status of farms of Creole and Creole-like pigs in Martinique
}

\author{
Jean-Luc Gourdine ${ }^{*}$ Alain Lof ${ }^{2}$ Jonathan Louis-Sidney ${ }^{2}$ \\ Willy Delyon ${ }^{3}$ Ivan Semjen ${ }^{3}$ Katia Benony ${ }^{4}$ Mélain Bructer ${ }^{4}$ \\ Mélissa Cyril $^{5}$ Valérie Gauthier ${ }^{6}$ Gisèle Alexandre ${ }^{1}$
}

\section{Keywords}

Swine, creole pig, rearing systems, typology, Martinique

Submitted: 31 August 2017
Accepted: 21 January 2019
Published: 8 February 2019
DOI: 10.19182/remvt.31346

\section{INTRODUCTION}

In Martinique $\left(14^{\circ} 36^{\prime} \mathrm{N}, 61^{\circ} 4^{\prime} \mathrm{W}\right)$, local pig meat is provided by traditional and family pig farms (with small numbers of animals) and 65 industrial farms belonging to one of the two pig cooperatives. Little information on the type of breeds, feeding system or sanitary status is available in the traditional pig farms because most of them are in

\footnotetext{
1. INRA, UR0143 URZ, 97170 Petit-Bourg, Guadeloupe.

2. PNM, 97205 Fort-de-France, Martinique.

3. Ruralité-Multiservices, 97257 Fort-de-France, Martinique.

4. INRA, UE503 PTEA, 97170 Petit-Bourg, Guadeloupe.

5. COOPMAR, 97232 Le Lamentin, Martinique.

6. Chambre d'Agriculture de Martinique, 97232 Le Lamentin, Martinique.

* Corresponding author

Tel.: +590 (0) 2559 42; Fax: +590 (0) 255936

Email: Jean-Luc.Gourdine@inra.fr
}

\begin{abstract}
Summary
The study aimed at characterizing the management of 27 pig farms in the framework of a conservation program of the Creole pig of Martinique. Blood samples were collected on 67 pigs for serological analysis. A multivariate analysis discriminated six groups of farms: group $1(n=9)$ consisted of family farms with fewer than three boars and a higher age of replacement of reproducers than the other farms (6.2 vs 5.0 years, $p<0.01)$; group $2(n=5)$ consisted of small farms with two matings per sow per year and with more than two livestock species; group $3(n=5)$ consisted of farms with more than four boars and more than four sows, with batch management and a feeding diet mainly based on industrial concentrates; group $4(n=4)$ consisted of family farms with pigs reared outdoors and a feeding diet mainly based on local resources (50 to $100 \%$ of the total diet content); group $5(n=3)$ consisted of mixed farming systems with more than three boars and more than 10 sows; and group 6 consisted of a farm with a high number of females without batch management. The analysis of serological data showed that, regardless of the farming system (outdoor, semi outdoor, indoor), the sanitary status of pig farms in Martinique was good, with no identified contagious disease. The typology obtained and the results on the sanitary status of farms are encouraging signs to pursue the project aiming at the conservation of Creole pigs by exchange of healthy reproducers between farmers and the development of a niche market around heritage values.
\end{abstract}

- To quote this article: Gourdine J.-L., Lof A., Louis-Sidney J., Delyon W., Semjen I., Benony K., Bructer M., Cyril M., Gauthier V., Alexandre G., 2018. Characterizing practices and the sanitary status of farms of Creole and Creole-like pigs in Martinique. Rev. Elev. Med. Vet. Pays Trop., 71 (1-2): 33-39, doi: 10.19182/ remvt.31346

the informal sector, where pig production is a part of the agricultural production of the pig farmers. On the other hand, the industrial farms are well characterized (Agreste, 2016), and the average number of sows is about 42 (COOPMAR, pers. commun.).

The local Creole pig of Martinique (CpM) has played a major part in the subsistence economy of small-scale farmers (Barrau, 1978). However, these small black pigs are now very rare because of indiscriminate breeding with imported exotic breeds, and the development of intensive pig systems with purchased feed and genetically improved exotic breeds. To our knowledge, the local pig of Martinique has not yet been characterized, nor has it been integrated into a research and conservation program. Like many countries on the American continent, $\mathrm{CpM}$ may be the result of a complex conglomerate of pigs from the Iberian Peninsula and other European pig populations (Burgos-Paz et al., 2013).

The Natural Park of Martinique (PNM) aims to maintain and valorize the genetic heritage of Martinique's biodiversity. PNM's medium-term objective is to develop a niche business with the local pig. 
This research and development project involves several stakeholders such as research (French National Institute for Agricultural Research [INRA]), management (an agricultural consultancy named Rurality-Multiservices), agricultural expertise (Regional Chamber of Agriculture [CA] and a pig farmers' cooperative [COOPMAR]), and farmers' empirical knowledge. The project seeks to characterize genetically the Creole pig breed of Martinique and to implement conservation and production focusing on ecosystem services such as meat quality, sociocultural services and circular economy (Gourdine et al., 2016). To reach this goal, it is essential to carry out an inventory of the local pig population.

To our knowledge, the characteristics of Creole-pig farming systems and its sanitary status are poorly documented. Our inventory allowed addressing these knowledge gaps in Martinique. Based on PNM data, some Creole pigs live freely in the mountains in the North, on the South Coast and on a few farms located in the countryside. The study aimed at creating a qualitative classification of farming systems in Martinique where Creole pigs or at least pigs looking phenotypically like Creole pigs are reared. A second objective was to assess the sanitary status in order to evaluate the possibility of exchanging reproducers (such as rotational mating schemes; Windig and Kaal, 2008) in the framework of PNM conservation program.

\section{MATERIALS AND METHODS}

\section{Survey}

We conducted a survey on a small number of pig farmers who stated rearing Creole pigs. At this stage of the experiment, results on the genetic analysis that distinguished the Creole breed from other breeds were not available. Consequently, farmers who reared Creole or Creole-like pigs (i.e., pigs that phenotypically looked like Creole pigs but were not genetically Creole pigs) were selected.

\section{Steps before the survey}

The survey was carried out between June and August 2016. Its objectives were: i) identify farmers who reared Creole or Creole-like pigs; ii) characterize the management of the pig production system and sanitary status; iii) explain to the farmer the long-term objective of PNM project (i.e. develop a niche market with Creole pigs of Martinique) and identify farmers who would like to participate in the project; iv) collect blood samples for further studies on $\mathrm{CpM}$ genetic structure. Contrary to conventional systems for which identification of farmers and farms is available, information on traditional pig farmers is scarce in public institutions. Consequently, various official and unofficial sources were used to have contacts. Some information was obtained from CA, PNM and COOPMAR. Some farmers' contacts were made through word-of-mouth or in answer to poster advertising, whose message invited anyone who had or knew people rearing Creole pigs to contact PNM, because the institute was looking for this local breed for conservation. The posters were published in places frequented by farmers such as feed providers and agricultural institutes. A total of 27 pig farmers were questioned by the staff of Rurality-Multiservices.

\section{Survey content}

The survey was based on 10 to 30 minutes' open conversations with farmers on their farms. Conversations aimed at collecting information on feeding, reproduction, drug administration, environmental management and product marketing. Figure 1 summarizes the information collected. Each discussion helped characterize the farmer (age and sex), farm management (reproduction, feeding, health), the type of sold pig product (e.g. live animals, meat), the characteristics of the agricultural system (e.g. does the farm also include crops or beef cattle), and labor in the pig system.

\section{Sanitary status}

\section{Collection and conservation of blood samples}

The long-term objective of the project is to maintain the Creole pig of Martinique by exchange of reproducers between Creole pig farmers. To achieve it, it was necessary to evaluate the sanitary status of Creole-pig farms and identify farmers who agreed to take part in the project. These farmers allowed us to take blood samples for DNA and serological analyses, and they agreed to become candidates for breeders of Creole pigs. To optimize blood sample collection by farmers' location, we set up five to six appointments per day with the farmers. Blood samples were collected by jugular venipuncture into two anticoagulant $6-\mathrm{ml}$ tubes per pig and stored at $4^{\circ} \mathrm{C}$ in a portable refrigerator. After all the farms were visited, they were transferred to the laboratory and maintained at room temperature for 15-30 min to allow blood to clot. The clot was removed by centrifuging for 10 min in a refrigerated centrifuge and the serum was apportioned into 0.5 -ml aliquots, stored at $4^{\circ} \mathrm{C}$ and transported immediately or the day after by plane under refrigeration to the French national laboratory for the control of reproducers located in Maisons-Alfort (LNCR, 2016).

\section{Sanitary analysis}

Analyses of the sera were performed by LNCR to check any sanitary problems about infectious pig diseases: classical swine fever (CSF), brucellosis, Aujeszky's disease (caused by Pseudorabies virus, PRV), porcine reproductive and respiratory syndrome (PRRS). A rose Bengal test (RBT) was used to detect Brucella suis. A serological test for the detection of antibodies to PRRS virus was carried out with an enzyme-linked immunosorbent assay (ELISA). We also performed a blocking ELISA for the detection of antibodies to gB antigen of PRV. CSF virus was tested on pig serum with a blocking ELISA test.

\section{Statistical analysis}

All statistical analyses were carried out with $\mathrm{R}$ version 3.2.5 (R Development Core Team, 2016). A principal component analysis (PCA) was performed with FactoMineR package (Lê et al., 2008) in R.

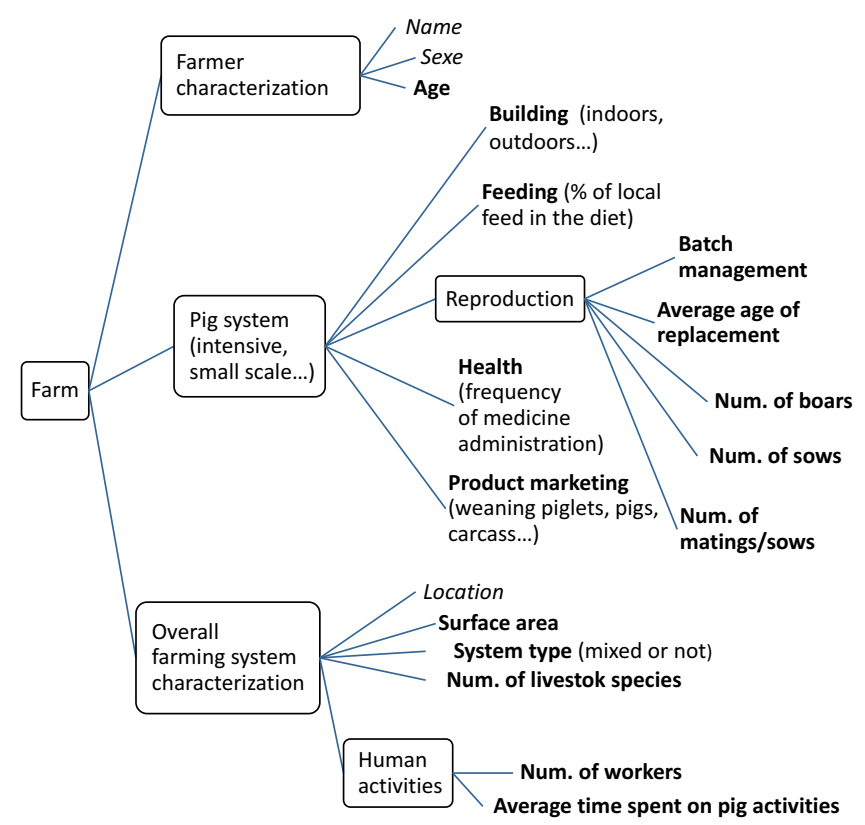

Figure 1: Information collected from conversations with farmers rearing Creole or Creole-like pigs in Martinique. Items without framing are variables used in statistical analyses. Items in bold correspond to quantitative variables. 
We chose this type of analysis because it summed up a dataset of individuals $\mathrm{x}$ variables. It helped characterize farms or groups of farms by the studied variables. PCA reduces the dimensionality of a dataset with a large number of interrelated variables while retaining as much as possible the variations present in the dataset (Jolliffe, 2002). PCA was carried out with 14 quantitative variables (Figure 1) as active variables, and 27 farming systems as individuals. To perform PCA, the five qualitative variables (building, batch management, health, product marketing and system type) were transformed into standardized notes by the first author of this article. Some information was missing on the total surface area of the whole farming system (about $52 \%$ of missing values), because some farmers in the informal sector did not know the surface area of their farms and others did not want us to know it, therefore PCA did not take into account this variable. The data was standardized before performing PCA because the 14 variables had different units (year, number, percentage, and minutes). Without standardization, each variable would have had the weight corresponding to its standard deviation, whereas with standardization each variable had the same weight. To help interpret the principal components, a variance analysis model was used for each component to explain the contribution of each variable with dimdesc function of FactoMineR.

A cluster analysis was then carried out with HCPC function of FactoMineR, based on the results of the PCA analysis. Hierarchical ascending clustering was performed with Ward method, which minimizes the decrease of inertia between groups when two groups are gathered into one. We chose to cut the tree at the optimal cut level proposed by HCPC. The cluster aimed at grouping the 27 farming systems so that farms in a same group were more similar to one another than to those in other groups (Rydhmer et al., 2014). HCPC also allows characterizing each group by sorting the studied variables according to a value obtained with Welch test. This statistic consists in testing whether the obtained value of each variable for the individuals of a given group is significantly different from the overall mean.

A

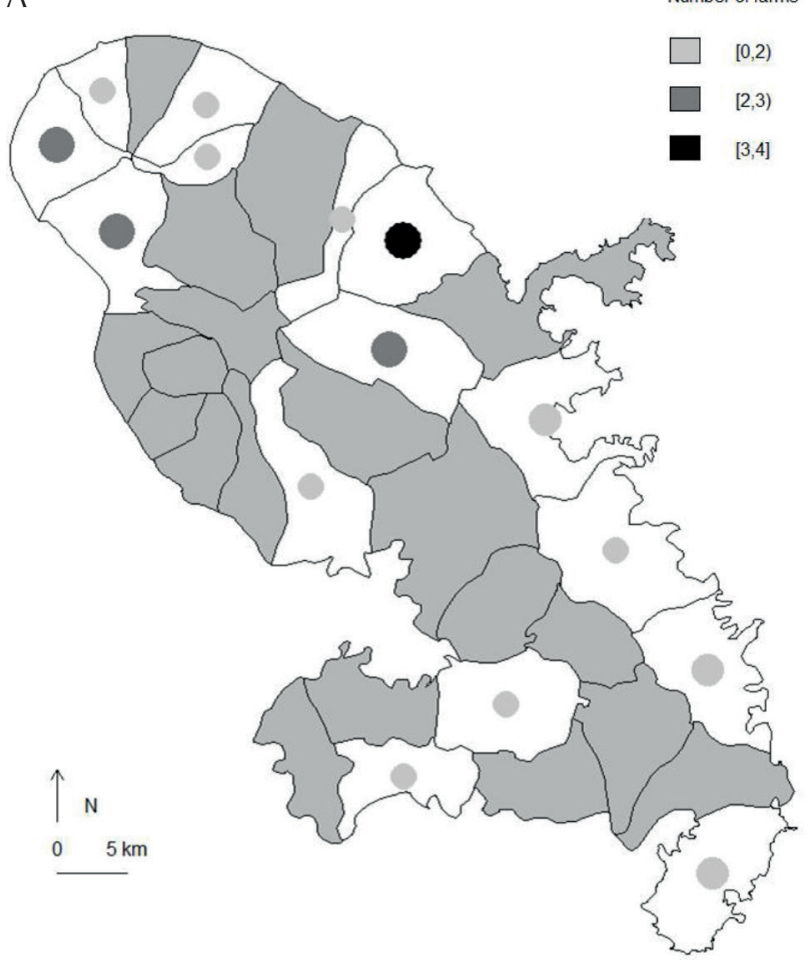

\section{RESULTS AND DISCUSSION}

Figure 2A shows the 27 pig farms distributed throughout Martinique Island. Figure 2B shows the number of sampled pigs. The areas where no farmers were questioned were mainly touristic areas (South and North-West in grey), urban areas or areas with declining agricultural activities. The farms were located on 16 of the 34 districts of Martinique. Farmers were between 30 and 72 years old. Only one farmer was a female and $22 \%$ of the farmers were professional pig producers belonging to one of the two pig cooperatives.

In most American countries where Creole pigs are present (Burgos-Paz et al., 2013), these animals are reared in non-conventional production systems such as mixed farming. Martinique is characterized by an important rural cultural heritage, where pig production in the informal sector remains substantial and is maintained by non-professional farmers or people having another job besides that of farmer. The number of 21 amateur farms might not represent the supposed number of informal family farms (CA, 2016). However, these 21 farms are distributed across the countryside of Martinique, suggesting that they might be representative of common practices of farmers rearing Creole or Creole-like breeds.

The 27 surveyed farmers reared pigs that looked like Creole animals. According to a phenotypic description, the Creole pig is colored, from piebald (white and black spotted) to wholly black, lop-eared and sometimes with the presence of pendants under the neck; it is rather small, fatter and a slower grower than exotic breeds such as Large White, Duroc or Pietrain. The genetic composition of Creole pigs in the Caribbean (note that results are not yet available for pigs in Martinique) shows that they originate from a complex conglomerate of several breeds, with the highest admixture of pigs from the Iberian Peninsula and Canary Islands, as a result of Spanish and Portuguese colonization of America in the 16th century (Burgos-Paz et al., 2013). At this stage of the project, the results on the genetic analysis are

B

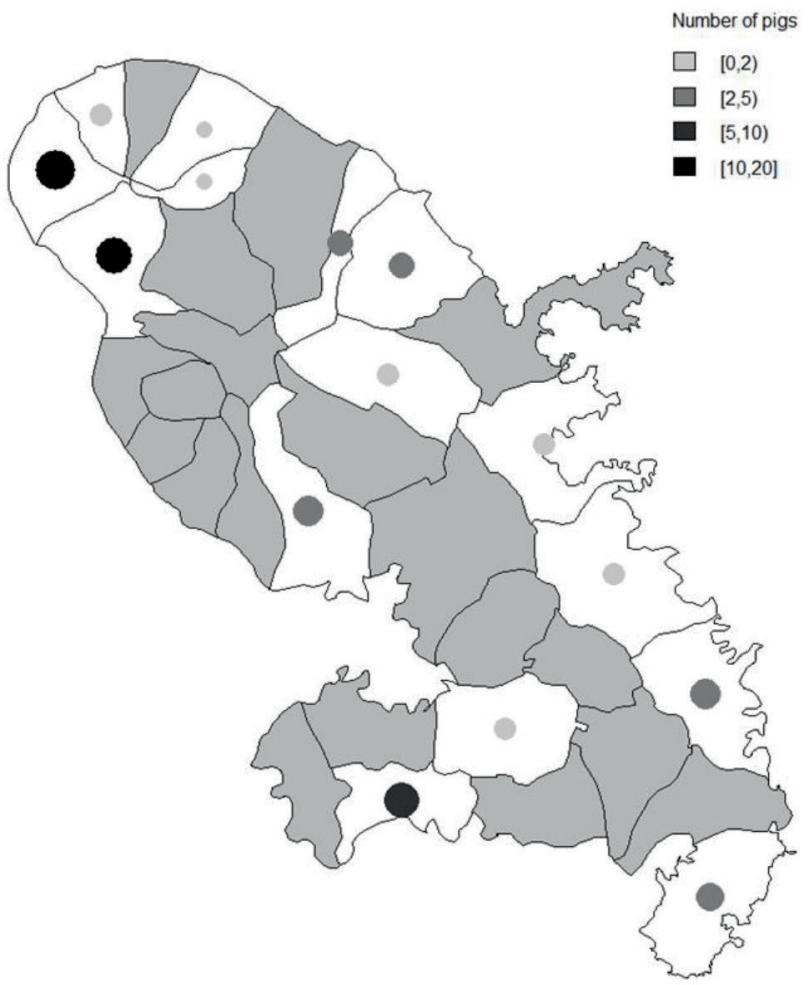

Figure 2: Geographical location of farms (white sections) in the 34 sections of Martinique. A) Number of farmers who accepted to answer the survey (circles). B) Number of Creole or Creole-like pigs sampled for serological analyses (circles). 
not yet available, so the difference between real Creole pigs and Creole-like pigs cannot be made.

Only 10 pig farmers practiced batch management of sows. This was probably because the majority of the farmers had a small pig production of fewer than three sows. Furthermore, in these small pig production systems, reproduction management tended to depend much more on feed availability (i.e. produced on the farm) and market demands (often higher in December because of the Christmas tradition) than on the reproductive cycle per se of sows.

Only $18 \%$ of farmers (all professional) did not use local feed resources but bought industrial concentrates. It is noteworthy that $30 \%$ of farmers did not use drugs, suggesting the robustness of their pigs or the use of alternative solutions to treat endo- and ecto-parasitism and diseases.

The first four principal components (PC) of PCA accounted for $66 \%$ of the total variance. The first PC explained $34 \%$ of the total variation (Figure 3A). It seemed that the first PC covered the overall farming system characteristics and animal husbandry practices (feeding, reproduction and health management). The variables that contributed most to the first PC were in descending order of importance $(p<0.01)$ : production, feeding management, number of livestock species, health management, number of sows, average time spent in pig activities, number of boars. Based on the correlation of 0.74 and -0.70 of the first $\mathrm{PC}$ with production and feeding management, respectively, the first axis can be viewed as a measure of the type of agricultural system, with at the extremes i) multi-livestock or crop-livestock farms using commercial concentrate diets as main feed, and ii) small pig farms mainly using local feed resources.

The second PC explained $12 \%$ of the total variation. Variables contributing most to the second $\mathrm{PC}$ were the number of matings per sow per year (correlation of 0.64 ), the number of sows (correlation of -0.53 ), and the marketing management (correlation of - 0.52 ). Consequently, the second PC seemed to cover the reproduction management of sows and marketing outlets. This suggests that farms with a higher number of matings per sow per year than the average population were those with a higher number of sows. These farms also tended to have less diversity in market products than farms with less intensive reproduction management.

The third and fourth PC explained 10\% and $9 \%$ of the total variation, respectively (Figure 3B). Five variables significantly $(p<0.05)$ characterized the third PC: number of workers (correlation of -0.58), number of boars (correlation of 0.48 ), average time spent in pig activities (correlation of 0.48), production (correlation of -0.40), and reproduction management (correlation of 0.38 ). The forth PC was significantly $(\mathrm{p}<0.05)$ characterized by the pig building system (correlation of 0.79$)$ and the age of the farmer (correlation of -0.67).

The cluster analysis based on PCA results identified six groups. As described in Figure 4, the lowest number of homogenous groups should correspond to the highest difference in height of the sticks, which is between Groups 5 and 6 . Table I shows that Group $1(\mathrm{n}=9)$ only comprised 35-65 year-old farmers who were not members of a pig cooperative. The cluster analysis showed that Group 1 consisted of family farms with fewer than three boars and a higher age of replacement of reproducers than the other farms ( 6.2 vs 5.0 years, $\mathrm{p}<0.01$ ). The majority of farmers in Group 1 only reared pigs. Group $2(n=5)$ consisted of small farms with two matings per sow per year, with more than two livestock species. Group $3(n=5)$ consisted of farms with more than four boars and more than four sows, with batch management and a feeding diet mainly based on industrial concentrates. Group $4(n=4)$ were family farms with pigs reared exclusively outdoors and fed a diet mainly based on local resources (50 to $100 \%$ of the total diet content). Group $5(n=3)$ consisted of mixed farming systems with more than three boars and more than ten sows. In this group, the average time spent in pig activities was significantly higher than the average mean (170 vs $98 \mathrm{~min}$, $\mathrm{p}<0.05$ ). Group 6 cluster was made of only one farm (F12) with a high number of females without batch management (Table I). Consequently, the multivariate analysis revealed substantial differences in the pig farming systems with regard to characteristics such as the number of reproducers and the feeding or reproductive management, or overall farming system characteristics such as the number of livestock species reared.

Except in Groups 5 and 6, farmers used local feed resources high in energy such as banana fruit (green or mature), roots, tubers such as cassava (Manihot esculenta), sweet potatoes (Ipomea batatas), coconuts, sugarcane (Saccharum officinarum), and residues from the harvest of vegetables. The quantity offered to pigs depended on the availability of the local resources (e.g. season, amount of residues), so that it was difficult to quantify accurately the amount of local resources in the pig diet.

In the present study, the conventional pig production system was defined as the systems integrated in the formal network of the pig industry of Martinique (pig cooperative, slaughterhouse, mass distribution). According to the cluster analysis, the non-conventional systems were in five of the six clusters, whereas the conventional systems were positioned in
$A$

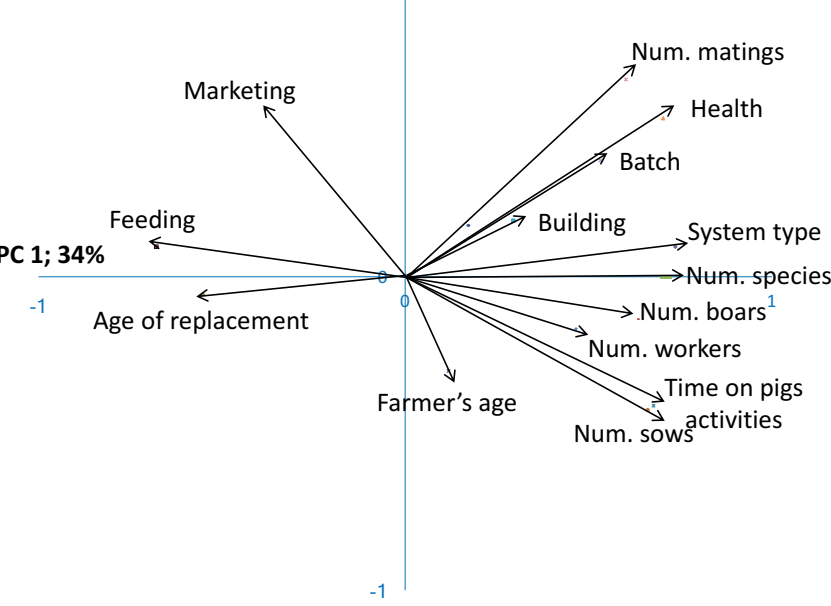

B

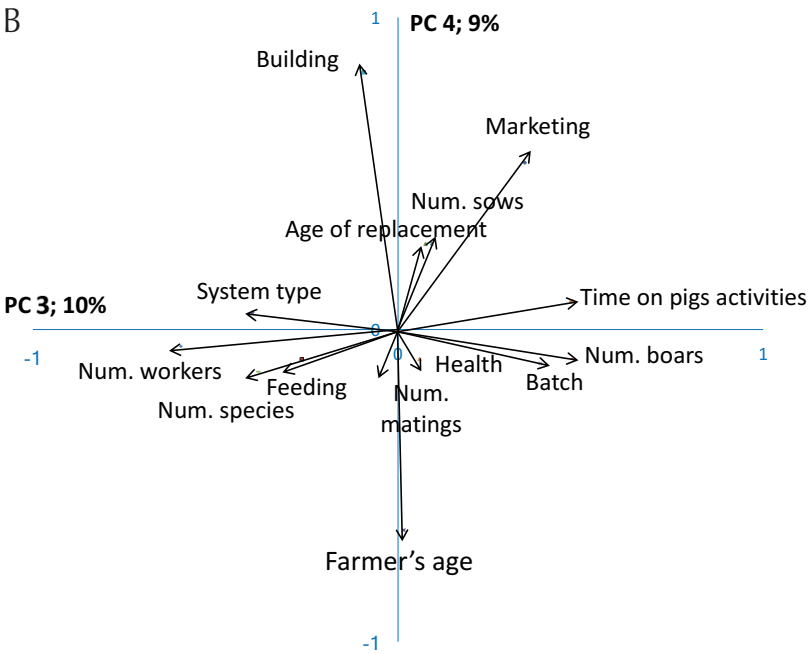

Figure 3: Map of the 14 active variables that participated in the principal component analysis (PCA), with a view to characterize Creole and Creole-like pig farms in Martinique; $A$ ) on the first (PC 1) and second (PC 2) axes of the PCA; and B) on the third (PC 3) and forth (PC 4) axes. 
A

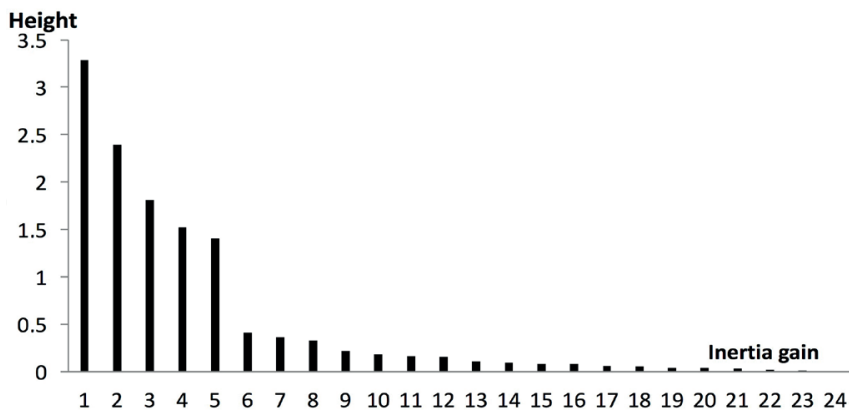

Figure 4: Characterizing Creole and Creole-like pig farms in Martinique. A) Inertia gain from the hierarchical ascending cluster analysis. B) Hierarchical tree with the six clusters. The dotted line corresponds to the optimal clustering level obtained with the cluster analysis and it delineates six groups of systems. Letter C defines conventional pig production systems integrated into a pig cooperative; letter F corresponds to small-scale pig systems.

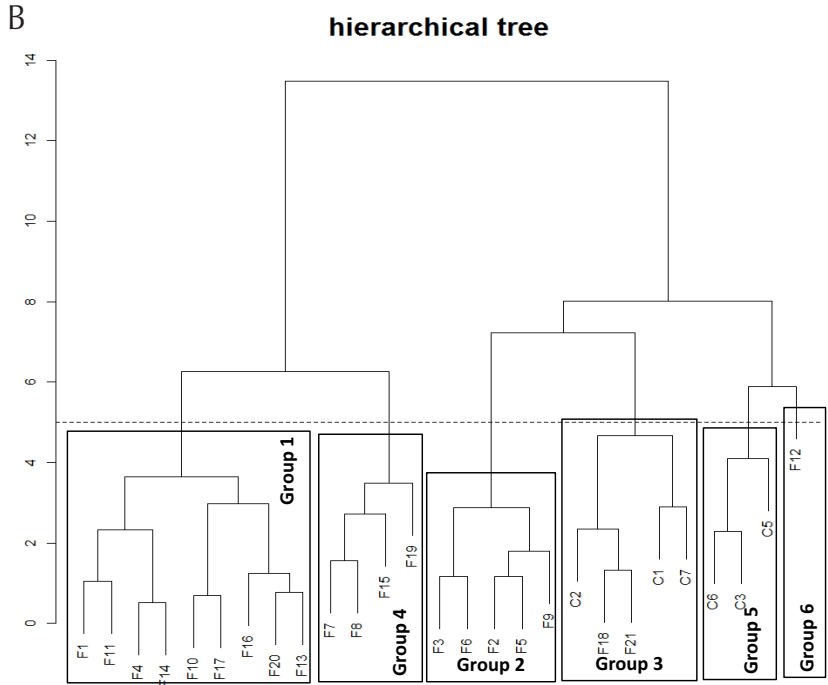

Table I

Characteristics of Creole and Creole-like pig systems in Martinique

\begin{tabular}{|c|c|c|c|c|c|c|}
\hline & \multicolumn{6}{|c|}{ Farming system types } \\
\hline & Group $1(n=9)$ & Group $2(n=5)$ & Group $3(n=5)$ & Group $4(n=4)$ & Group $5(n=3)$ & Group $6(n=1)$ \\
\hline Farmer's age (years) & $45(35-65)$ & $44(30-58)$ & $50(36-60)$ & $59(45-72)$ & $57(55-60)$ & 54 \\
\hline Num. cooperative members & 0 & 0 & 3 & 0 & 3 & 0 \\
\hline Pig building system & & & & & 1 & \\
\hline Outdoors & 5 & 0 & 1 & 4 & 0 & 0 \\
\hline Indoors & 2 & 3 & 1 & 0 & 2 & 0 \\
\hline Both & 2 & 2 & 3 & 0 & & 1 \\
\hline$\%$ of local feed in pig diet & $\begin{array}{l}<50 \%: 1 \text { farm } \\
\text { 50-75\%: } 8 \text { farms } \\
>75 \%: 0 \text { farm }\end{array}$ & $\begin{array}{l}<50 \%: 1 \text { farm } \\
\text { 50-75\%: } 1 \text { farm } \\
>75 \%: 3 \text { farms }\end{array}$ & $\begin{array}{l}<25 \%: 4 \text { farms } \\
50-75 \%: 1 \text { farm } \\
>75 \%: 0 \text { farm }\end{array}$ & $\begin{array}{c}<50 \%: 0 \text { farm } \\
\text { 50-75\%: } 2 \text { farms } \\
>75 \%: 2 \text { farms }\end{array}$ & $\begin{array}{l}<25 \%: 3 \text { farms } \\
<50 \%: 0 \text { farm } \\
\text { 50-75\%: } 0 \text { farm }\end{array}$ & $\begin{array}{l}<25 \%: 1 \text { farm } \\
<50 \%: 0 \text { farm } \\
50-75 \%: 0 \text { farm }\end{array}$ \\
\hline Batch management & 1 farm & 2 farms & 5 farms & 0 farm & 2 farms & 0 farm \\
\hline Num. Creole/Creole-like boars & rs $1.4(0-3)$ & $1.2(1-2)$ & $4.2(3-6)$ & $2.5(0-4)$ & $3.7(3-4)$ & 3 \\
\hline Num. Creole/Creole-like sows & s $\quad 2.7(1-5)$ & $2.4(1-3)$ & $5.6(3-8)$ & $3.2(1-7)$ & $14.3(8-25)$ & 25 \\
\hline Age of replacement (years) & $6.2(4.5-8)$ & $4.9(4.5-5)$ & $4.9(3-8)$ & $4(2-5)$ & $3.3(2.5-4.5)$ & 5 \\
\hline Num. matings / sows & $1.1(1-2)$ & 2 & 2 & $1.2(1-2)$ & 2 & 1 \\
\hline \multicolumn{7}{|l|}{ Veterinarian's intervention } \\
\hline Never & 7 & 1 & 0 & 0 & 0 & 0 \\
\hline Casual & 2 & 3 & 2 & 3 & 0 & 1 \\
\hline Always & 0 & 1 & 3 & 1 & 3 & 0 \\
\hline \multicolumn{7}{|l|}{ Type of agricultural system } \\
\hline Pigs only & 6 & 0 & 0 & 0 & 0 & 0 \\
\hline Multi-livestock & 2 & 0 & 3 & 3 & 0 & 0 \\
\hline Crops-livestock & 1 & 5 & 2 & 1 & 3 & 1 \\
\hline Number of workers & $1.2(1-2)$ & $1.5(1-2)$ & 1 & $1.2(1-2)$ & $2.5(2-3)$ & 1 \\
\hline Time in pig activities (min) & $70(30-150)$ & $45(15-60)$ & $144(60-300)$ & $82(30-150)$ & $170(120-240)$ & 240 \\
\hline \multicolumn{7}{|c|}{ Jumeric variables: average values (in parentheses, minimum and maximum values); Categorical variables: figures correspond to the number of farms } \\
\hline \multicolumn{7}{|c|}{$\begin{array}{ll}\text { two groups (Groups } 3 \text { and 5) with one group comprising only conven- } & \text { (following COOPMAR recommendations: batch and feeding manage- } \\
\text { tional farms (Group 5). As we expected, clusters with non-conventional } & \text { ment, prophylaxis, among others) so that the variability among them } \\
\text { farms were in greater number than clusters with conventional farms for } & \text { was expected to be lower than that among non-conventional farms. One } \\
\text { at least two reasons. Firstly, in our dataset, the number of conventional } & \text { farm stood alone in a group. This might seem surprising, but plots of } \\
\text { farms was lower than that of non-conventional farms (6 vs 21). Secondly, } & \text { each farm on the first four principal components (Figure 5A and B) } \\
\text { the management of conventional farms was generally well standardized } & \text { showed that farm F12 was isolated from the other farms. This farm }\end{array}$} \\
\hline
\end{tabular}




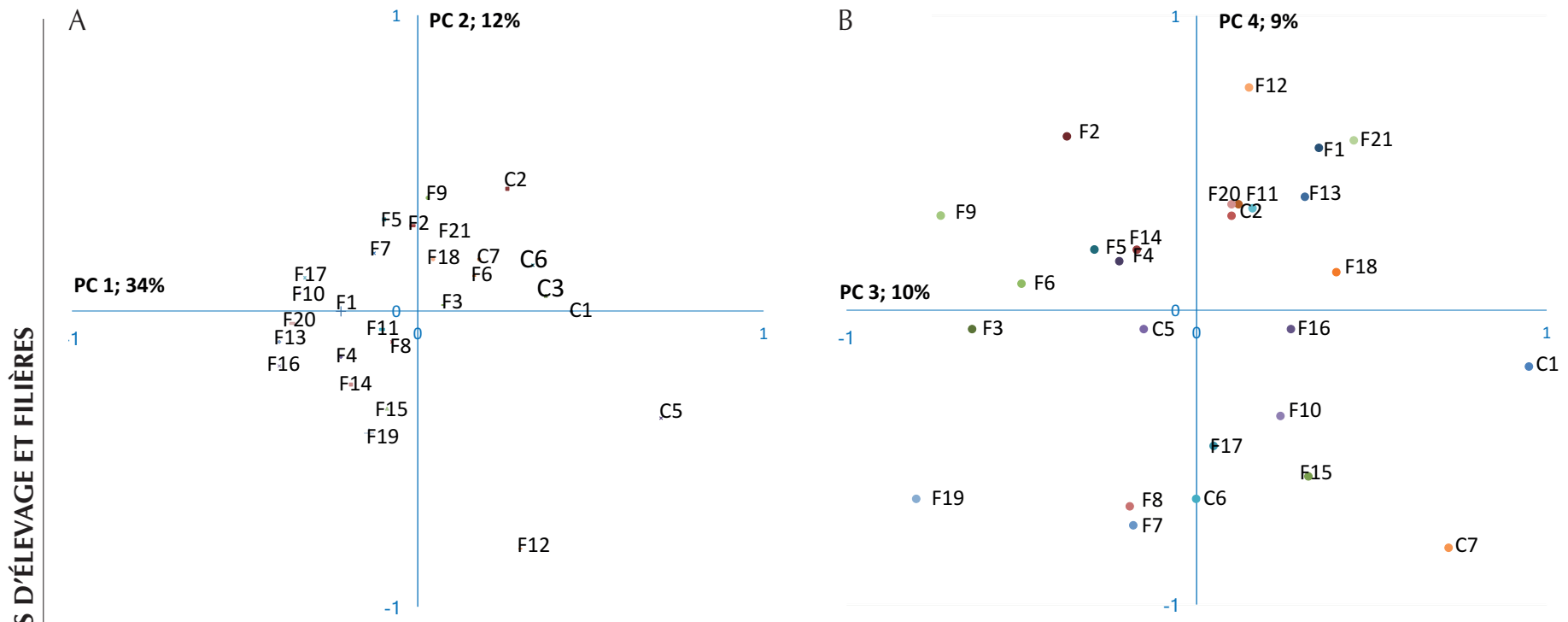

Figure 5: Characterizing Creole and Creole-like pig farms in Martinique. Map of the 27 farming systems: A) on the first (PC 1) and second (PC 2) axes of the principal components analysis (PCA), and B) on the third (PC 3) and forth (PC 4) axes. Letter $C$ defines conventional pig production systems integrated into a pig cooperative; letter F corresponds to small-scale pig systems.

was typical because the pig building and the number of sows $(n=25)$ were those of an intensive system in Martinique although the farm worked without batch management.

The groups obtained through PCA and the cluster analysis depended on the data and particularly on the accuracy of the discussion between the person answering the questions and the person asking them. Characterizing the 27-pig farming systems could be improved by a more in-depth questionnaire, quantitative data such as measurements, but too many questions would increase the risk of annoying farmers and thus losing the connection with them for future collaboration. It should be noted that no financial compensation was given to farmers at this stage of the project. Farmers who accepted to answer the survey were motivated by the global project aiming at the conservation and use of the Creole pig of Martinique in the local meat market. Furthermore, farmers in the informal sector were also motivated as they appreciated the fact that research took into account their practices without value judgments.

Blood samples were collected from 67 pigs in 22 farms (Figure 2B). Among these animals, seven were feral pigs captured in the northeastern part of Martinique. With regard to the health status, results showed that all animals were RBT negative, which meant that Brucella was not detected, even in feral pigs and in pigs reared outdoors, although brucellosis occurs in North and South America, with a high prevalence in wild pigs (Hernàndez-Mora et al., 2017). After exposure to $B$. suis, common signs of brucellosis are abortion, temporary or permanent infertility, lameness in sows and painful testicles in boars. In the present study, antibodies against PRRS virus were not detected. Controlling PRRS is a priority because this highly contagious disease has a major economic impact on pig production worldwide (Nathues et al., 2017) and represents an important health challenge in South America. PRRS is responsible for reproductive disorders in sows, respiratory problems in pigs and a general malaise (Carr, 2006). In the present study, pigs were not affected by PR virus as there was no detection of antibodies in the sera. This herpes virus can persistently affect the reproductive performance (Carr, 2006). Finally, all the farms were free of CSF virus. The control and eradication of CSF is one of the priorities identified in the Caribbean (CaribVet, 2017).

Based on the overall serological results, no well-known infectious disease was detected. We thus suggest that the sanitary status of pig farms in Martinique is very good in all types of pig farming systems, i.e. conventional in building, outdoors or semi-outdoors. Although the sanitary status is not static and can evolve badly, depending on the global and local health maintenance of pig farms in Martinique, the serological results suggest that the conservation of the local Creole pig of Martinique should be easily organized by exchange of healthy reproducers to restrict the inbreeding rate (Windig and Kaal, 2008; Pattison et al., 2007).

\section{CONCLUSION}

The impact of our approach is more qualitative than quantitative due to the small number of farmers who accepted to answer the survey. Nevertheless, we showed that diverse pig farming systems rearing Creole or Creole-like pigs exist in Martinique. To our knowledge, no previous study has been carried out on these types of pig systems, particularly in the informal sector. Our results revealed that farmers who reared only pigs could be distinguished from farmers who reared several livestock species and from crop-livestock farmers. Furthermore, they showed a diversity of management related to reproduction, feeding or medicine. The discussions with the farmers provided a more accurate idea of the management of the Creole pig breed of Martinique. Based on our typology, advices on feeding, reproduction and prophylaxis could be proposed to improve Creole pig production according to the type of farming. Serological results showed that pig production exhibited a good sanitary status without positive cases of the main dangerous contagious diseases. With the objective of conservation of the Creole pig of Martinique, it would be thus opportune to implement schemes based on the exchange of reproducers between Creole-pig farmers without risks of sanitary problems. Our typology is a benchmark for PNM project, which aims at maintaining Creole pigs by the development of a niche market around the heritage values of Martinique.

\section{Acknowledgments}

The authors gratefully acknowledge PNM and the Territorial Collectivity of Martinique (CTM) for this integrated project. They also wish to thank warmly the farmers who took the time to discuss and respond to the questionnaires. 


\section{REFERENCES}

Agreste, 2016. Martinique. Memento of agricultural statistics. Direction de I'alimentation, de l'agriculture et de la forêt de la Martinique, Fort-de-France, Martinique, http://daaf.martinique.agriculture.gouv.fr/ (accessed 11 Nov. 2016)

Barrau J., 1978. On the "cochon-planche" of small West Indies. J. Agric. Trad. Bota. Appl., 25 (3): 195-201, doi: 10.3406/jatba.1978.3770

Burgos-Paz W., Souza C.A., Megens H.J., Ramayo-Calsdas Y., Melo M., LemusFlores C., Caal E., et al., 2013. Porcine colonization of the Americas: a 60k SNP story. Heredity, 110: 321-330, doi: 10.1038/hdy.2012.109

CA, 2016. Overview of the agriculture of Martinique. Chambre régionale d'agriculture, Le Lamentin, Martinique, www.martinique.chambagri.fr (accessed July 18, 2017)

CaribVet, Caribbean Animal Health Network, 2017. Eradicate classical swine fever in the Caribbean. USDA, CENSA, CIRAD, FAO, OIRSA, OIPORC, www.caribvet.net/publications/press-release/erradicar-la-peste-porcinaclasica-del-caribe (accessed 11 Aug. 2017)

Carr J., 2006. The maintenance of health. In: Whittemore's Science and practice of pig production (Eds. Kyriazakis I., Whittemore C.T.). Blackwell, Oxford, UK, 263-316, doi: 10.1002/9780470995624.ch7

Gourdine J.-L., Lof A., Brithmer R., Hoche-Balustre S., Servier M.-F., Bructer M., Benony K., et al., 2016. Research framework for the development of Creole pig's niche market in Martinique: a holistic approach. In: Caribbean Food Crops Society annual meeting, Guadeloupe, France, 10-16 July 2016. INRA Centre Antilles-Guyane, Le Gosier, Guadeloupe, p. 4
Hernàndez-Mora G., Bonilla-Montoya R., Barrantes-Granados O., EsquivelSuàrez A., Montero-Caballero D., Gonzàlez-Barrientos R., Fallas-Monge Z., et al., 2017. Brucellosis in mammals of Costa Rica: An epidemiological survey. Plos One, 12 (8): e0182644, doi : 10.1371/journal.pone.0182644

Jolliffe I.-T., 2002. Principal component analysis, 2nd Edn. Springer, USA

Lê S., Josse J., Husson F., 2008. FactoMineR: An R package for multivariate analysis. J. Stat. Softw., 25: 1-18, doi: 10.18637/jss.v025.i01

LNCR, 2016. www.Incr.org (accessed 6 Sept. 2016)

Nathues H., Alarcon P., Rushton J., Jolie R., Feibig K., Jimenez M., Geurts V., et al., 2017. Cost of porcine reproductive and respiratory syndrome virus at individual farm level. An economic disease model. Prev. Vet. Med., 142: 1629, doi: 10.1016/j.prevetmed.2017.04.006

Pattison J., Drucker A.G., Anderson S., 2007. The cost of conserving livestock diversity? Incentive measures and conservation options for maintaining indigenous Pelon pigs in Yucatan, Mexico. Trop. Anim. Health Prod., 39: 339-353, doi: 10.1007/s11250-007-9022-4

R Development Core Team, 2016. R: A language and environment for statistical computing. R Foundation for Statistical Computing, Vienna, Austria, www.Rproject.org (accessed 30 Sept. 2016)

Rydhmer L., Gourdine J.L., de Greef K., Bonneau M., 2014. Evaluation of the sustainability of contrasted pig farming systems: breeding programs. Animal, 8 (12): 2016-2026, doi: 10.1017/S175173111400216X

Windig J.J., Kaal L., 2008. An effective rotational mating scheme for inbreeding reduction in captive populations illustrated by the rare sheep breed Kempisch Heideschaap. Animal, 2 (12): 1733-1741, doi: 10.1017/ S1751731108003029

\section{Résumé}

Gourdine J.-L., Lof A., Louis-Sidney J., Delyon W., Semjen I., Benony K., Bructer M., Cyril M., Gauthier V., Alexandre G. Caractérisation des pratiques et de l'état sanitaire des élevages de porcs Créoles et typés Créoles en Martinique

L'étude a eu pour objectif de caractériser la gestion de 27 élevages de porcs dans le cadre d'un programme de conservation du porc Créole de la Martinique. Des échantillons sanguins ont été prélevés sur 67 porcs pour des analyses sérologiques. Une analyse multivariée a distingué six groupes d'élevage : le groupe $1(n=9)$ correspondait aux élevages familiaux comptant moins de trois verrats et présentant un âge de réforme des reproducteurs plus élevé que les autres élevages (6,2 vs 5,0 ans, $\mathrm{p}<0,01)$; le groupe $2(\mathrm{n}=5)$ était constitué de petits élevages avec deux saillies par truie par an et avec plus de deux espèces de bétail élevées; le groupe $3(n=5)$ était composé d'élevages de plus de quatre verrats et de plus de quatre truies, avec une conduite en bande et une alimentation basée principalement sur du concentré industriel ; le groupe $4(n=4)$ correspondait à des élevages familiaux avec des porcs élevés en plein air et alimentés principalement avec des ressources locales (50 à $100 \%$ de la ration); le groupe $5(\mathrm{n}=3)$ était constitué d'agriculteurs en système polyculture-polyélevage avec plus de trois verrats et plus de dix truies; et le groupe 6 se distinguait par un nombre important de femelles $(n=25)$ sans conduite en bande. L'analyse des données sérologiques a montré que la situation sanitaire de ces élevages porcins en Martinique était excellente, sans maladie contagieuse identifiée, en bâtiment comme en plein air ou semi-plein air. La typologie obtenue et les résultats sur le statut sanitaire des fermes sont des signes encourageants pour poursuivre le projet de conservation des porcs Créoles par des échanges de reproducteurs sains entre les éleveurs et par le développement d'un marché de niche autour des valeurs patrimoniales.

Mots-clés : porcin, porc créole, système d'élevage, typologie, Martinique

\section{Resumen}

Gourdine J.-L., Lof A., Louis-Sidney J., Delyon W., Semjen I., Benony K., Bructer M., Cyril M., Gauthier V., Alexandre G. Caracterización de las prácticas y del estado sanitario de granjas de cerdos Criollos y tipo-Criollo en Martinica

El objetivo de este estudio fue caracterizar el manejo de 27 granjas porcinas en el marco de un programa de conservación del cerdo Criollo de Martinica. Se recolectaron muestras de sangre en 67 cerdos para análisis serológico. Un análisis multivariado discriminó seis tipos de granjas: el tipo $1(n=9)$ consistía en granjas familiares con menos de tres verracos y una edad de reemplazo de reproductores más alta que las otras granjas (6,2 vs 5,0 años, $\mathrm{p}<0,01)$; el tipo $2(\mathrm{n}=5)$ consistía en fincas pequeñas con dos apareamientos por cerda por año y con más de dos especies de animales domésticos; el tipo $3(n=5)$ consistía en granjas con más de cuatro verracos y más de cuatro cerdas, con manejo de lotes y una alimentación basada principalmente en concentrados industriales; el tipo $4(n=4)$ consistía en granjas familiares con cerdos criados al aire libre y una alimentación basada principalmente en recursos locales (50 a 100\% del contenido total de la dieta); el tipo $5(n=3)$ consistía en sistemas de cría mixto con más de tres verracos y más de 10 cerdas; y el tipo 6 consistía en una granja con un alto número de hembras sin manejo de lotes. El análisis de los datos serológicos mostró que el estado sanitario de las granjas de cerdos en Martinica es bueno, sin enfermedades contagiosas identificadas, en galpones como en exteriores o semi-exteriores. La tipología obtenida y los resultados sobre el estado sanitario de las fincas son signos alentadores para continuar con el proyecto de conservación de cerdos Criollo, mediante el intercambio de reproductores sanos entre productores y el desarrollo de un mercado selecto en torno a los valores patrimoniales.

Palabras clave: cerdo, puerco Criollo, sistemas de cría, tipología, Martinica 
